\title{
The origin of gypsum in Vertisols in New Caledonia determined by isotopic characteristics of sulphur
}

\author{
P. Podwojewski ${ }^{\mathrm{a}}$, M. Arnold \\ ${ }^{a}$ Institut de Géologie, Université Louis Pasteur, 1 rue Blessig, 67084 Strasbourg Cedex, France \\ ${ }^{b}$ Centre de Recherches Pétrographiques et Géochimiques, 15 rue N.D. des Pauvres, B.P. 20 , \\ 54501 Vandoeuvre-les-Nancy Cedex, France
}

Received November 21, 1991; accepted after revision November 12, 1993

\begin{abstract}
Gypsum crystals occur in Vertisols on the west coast of New Caledonia. These soils are derived from the weathering of basic rocks that contain no gypsum. The sulphur isotopic ratio ${ }^{34} \mathrm{~S} /{ }^{32} \mathrm{~S}$ was used as tracer to identify the origin of the gypsum. A total of 26 measurements of $\delta^{34} \mathrm{~S}$ were made on gypsum crystals from the Vertisols and compared to those of continental sulphates and to marine gypsum in tidal flats. The $\delta^{34} \mathrm{~S}$ value of the crystals located in New Caledonian Vertisols decreases with increasing distance from the coast. This suggests that the gypsum in the Vertisols comes from two sources: an oceanic source where the major part of the sulphur is introduced by atmospheric precipitation, and a continental source where sulphides disseminated in various subsurface deposits are oxidized. Gypsum from atmospheric precipitation penetrates the Vertisols through vertical cracks that probably formed in dry seasons during the last glacial period.
\end{abstract}

\section{Introduction}

The west coast of New Caledonia, which has a dry, subtropical, oceanic climate presents many topographically flat surfaces covered with "gypsiferous black clays" (Routhier, 1953; Avias, 1963) (Figs. 1 and 2). These clays are found on the leeward side of the island, where the yearly average rainfall ranges from 800 to $1100 \mathrm{~mm}$. Some authors have interpreted the "gypsiferous clays", of New Caledonia as marine deposits that formed under evaporitic conditions during a dry paleoclimate (Routhier, 1953; Avias, 1963) and that have been uplifted to their present elevation (10-170 $\mathrm{m}$ on Lepredour Island; Fig. 3) during the pre-Pleistocene tectonic movements (Gonord, 1977).

Most of the gypsum in New Caledonian soils occurs only in calcimagnesic Vertisols (Table 1; Podwojewski and Beaudou, 1991) derived from the weathering of basic rocks 


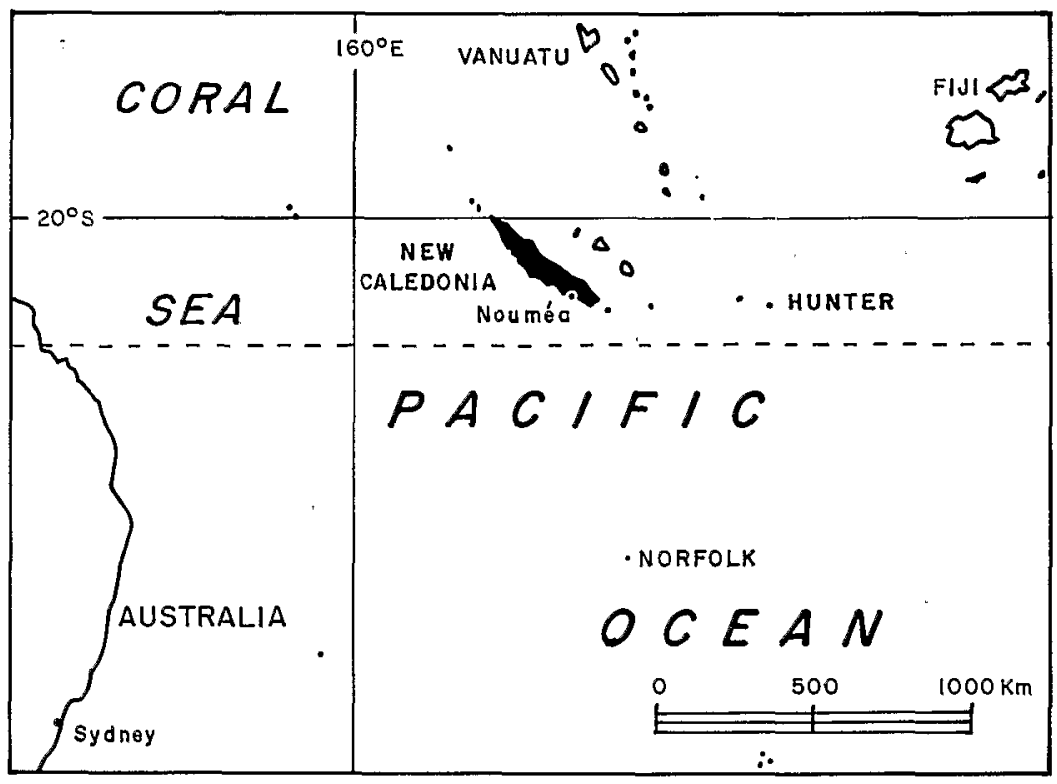

Fig. 1. Location map of New Caledonia.

such as non-gypsiferous flysch, basalts, or limestones. Gypsum-bearing soils lie in the lower part of soil catenas, overlying basic rocks, or on some high Pleistocene alluvial terraces. In the same areas, old alluvial terraces composed of hypermagnesic Vertisols (Podwojewski and Beaudou, 1991) derived from peridotites and serpentinites, and Planosols or solodized Solonetz derived from acidic rock (shales, sandstones, phtanites) (Podwojewski, 1988), however, do not contain gypsum.

Gypsum in New Caledonia accumulates at a depth greater than $80 \mathrm{~cm}$, within horizons containing more than $50 \%$ smectitic clays. Crystal sizes range from 0.5 to $3 \mathrm{~cm}$. They are lenticular in shape, and occur either as isolated crystals or in aggregates. In air-dried soil, gypsum constitutes 10 to $25 \%$ of the soil weight.

Recent considerations of Pleistocene tectonic movements and sea level changes in the South Pacific area indicate that sea level was never higher than $20 \mathrm{~m}$ above the current level in the studied zone (Bloom et al., 1974; Coudray, 1977; Cabioch, 1988), This implies that gypsum did not form in evaporitic basins along the Pleistocene marine shoreline. It is therefore believed that the gypsum is derived from the oxidation of sulphides in the bedrock and/or from the atmospheric supply of oceanic salts in rain.

Sulphur isotopes are appropriate tracers to deal with this problem of the origin of gypsum because the isotopic composition of marine and continental sulphates generally are different. Consequently, if two sources of sulphates are involved in the formation of gypsiferous soils, it is expected that a gradual change in sulphur isotopes will be observed with increasing distance from the coast. 


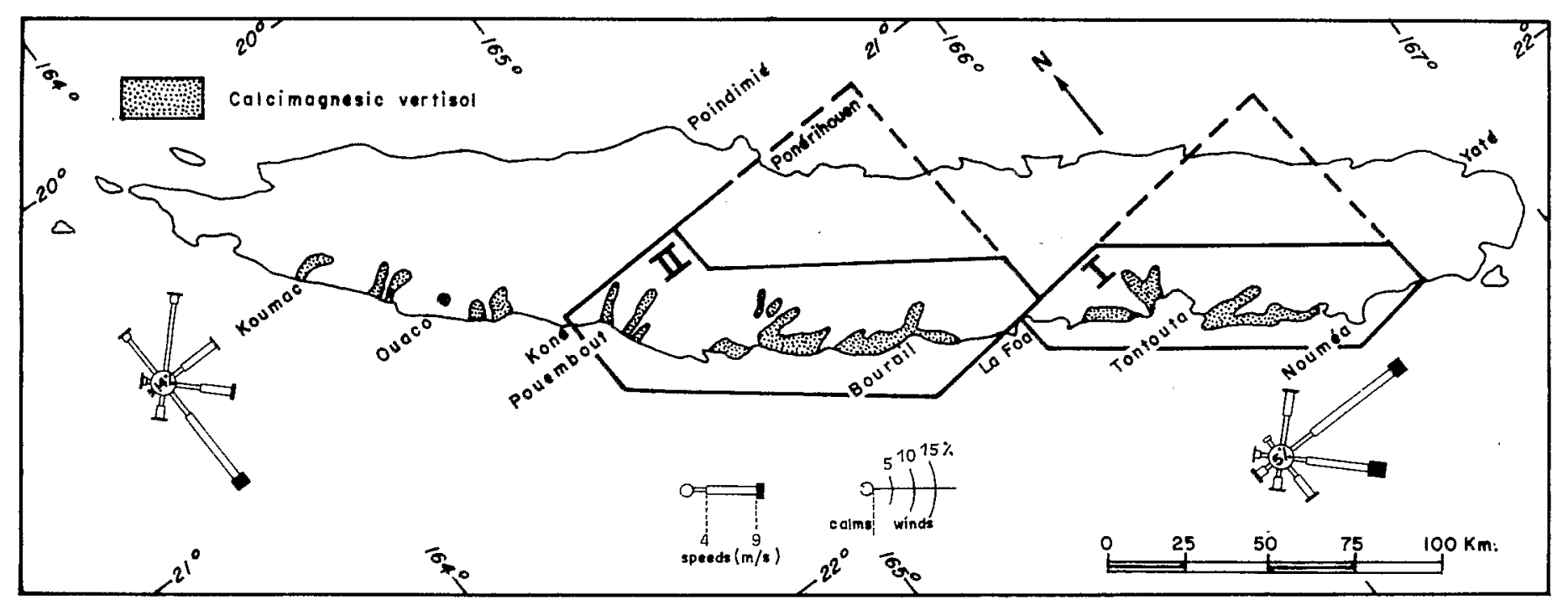

Fig. 2. Location of calcimagnesic Vertisols. Direction, velocity, and frequency of winds. I and II indicate the sampling location (see Fig. 3). 


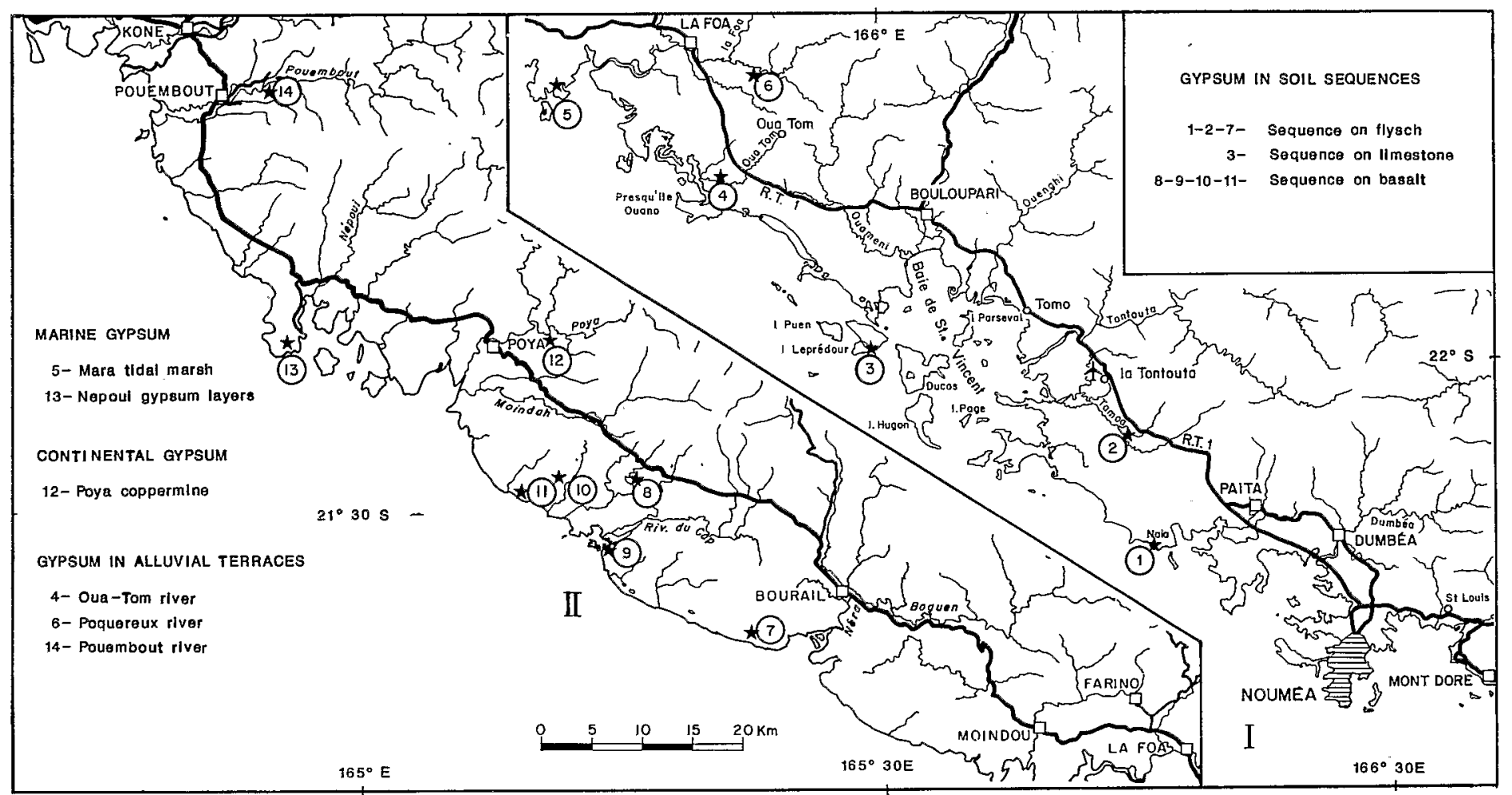

Fig. 3. Detail of Fig. 2. Location of gypsum sampling. Numbers refer to sample description, cf. Tables 2, 3, and 4. 
Table 1

Selected physical and chemical properties of some vertisols of New Caledonia. Vertisols B, C and D contain gypsum

\begin{tabular}{|c|c|c|c|c|c|c|c|c|c|c|}
\hline \multirow[t]{2}{*}{ Horizon } & \multirow{2}{*}{$\begin{array}{l}\text { Depth } \\
\text { (cm) }\end{array}$} & \multicolumn{3}{|c|}{ Texture (\%) } & \multirow{2}{*}{$\begin{array}{l}\mathrm{pH} \\
1: 2.5 \\
\left(\mathrm{H}_{2} \mathrm{O}\right)\end{array}$} & \multicolumn{4}{|c|}{ Exchangeable cations ${ }^{\mathrm{a}}\left(\mathrm{cmol} \mathrm{kg}^{-1}\right)$} & \multirow[t]{2}{*}{$\mathrm{CEC}$} \\
\hline & & clay & silt & sand & & $\mathrm{Ca}^{++}$ & $\mathrm{Mg}^{++}$ & $\mathrm{K}^{+}$ & $\mathrm{Na}^{+}$ & \\
\hline
\end{tabular}

\section{A. Vertisol on hard limestone (LEP 7)}

$\begin{array}{llllll}\text { A } & 0-20 & 68 & 18 & 14 & 7.1\end{array}$

$\mathrm{V}$

$80-100 \quad 69 \quad 16 \quad 15$

7.1

36.7

36.7

9.3

2.6

0.5

49.1

B. Vertisol on sandy limestone (LEP 25)

\begin{tabular}{|c|c|c|c|c|c|c|c|c|c|c|}
\hline & & & & & & & & & & \\
\hline A & $0-15$ & 45 & 23 & 32 & 6.9 & 26.2 & 7.2 & 1.6 & 0.7 & 40.0 \\
\hline$V_{G y}$ & $110-170$ & 75 & 3 & 22 & 6.4 & 21.7 & 9.8 & 0.3 & 7.8 & 36.9 \\
\hline
\end{tabular}

C. Calcimagnesic vertisol on flysch (MER 63)

$\begin{array}{lrlllllllll}\mathrm{A} & 0-20 & 48 & 34 & 18 & 5.9 & 12.0 & 14.7 & 0.8 & 0.6 & 36.2 \\ \mathrm{~V}_{\mathrm{Gy}} & 95-125 & 66 & 23 & 11 & 5.3 & 13.1 & 24.5 & 0.1 & 8.8 & 46.5\end{array}$

D. Acid and sodic vertisol on old alluvial terrace (TOM 001)

\begin{tabular}{|c|c|c|c|c|c|c|c|c|c|c|}
\hline A & $0-20$ & 35 & 42 & 23 & 6.0 & 11.4 & 6.4 & 0.2 & 0.7 & 23.4 \\
\hline $\mathrm{V}_{\mathrm{Gy}}$ & $100-120$ & 64 & 24 & 12 & 3.9 & 16.4 & 11.8 & 0.2 & 9.2 & 30.3 \\
\hline \multicolumn{11}{|c|}{ E. Hypermagnesic vertisol on old alluvial terrace (MER 72) } \\
\hline A & $0-20$ & 54 & 35 & 11 & 5.8 & 4.5 & 36.8 & 0.2 & 1.6 & 49.2 \\
\hline $\mathrm{V}_{\mathrm{Mg}}$ & $110-125$ & 54 & 29 & 17 & 8.6 & 2.4 & 38.1 & 0.3 & 2.5 & 41.6 \\
\hline
\end{tabular}

${ }^{a}$ From Tucker (1985).

\section{The isotopic composition of sulphur}

Sulphur has the following four stable isotopes: ${ }^{32} \mathrm{~S},{ }^{33} \mathrm{~S},{ }^{34} \mathrm{~S}$, and ${ }^{36} \mathrm{~S}$. Their abundances are $95.02 \%, 0.75 \%, 4.2 \%$, and $0.017 \%$, respectively. Sulphur isotope studies concern the variation of ${ }^{34} \mathrm{~S} /{ }^{32} \mathrm{~S}$ ratios. The sulphur isotopic composition of a sample is usually expressed as a $\delta^{34} \mathrm{~S}$ value, which is defined as follows:

$$
\delta^{34} \mathrm{~S} \text { sample }=\left(\frac{\left({ }^{34} \mathrm{~S} /{ }^{32} \mathrm{~S}\right) \text { sample }}{\left({ }^{34} \mathrm{~S} /{ }^{32} \mathrm{~S}\right) \text { standard }}-1\right) \times 1000
$$

The standard reference is the troilite phase of the Cañon Diablo (Arizona, USA) meteorite (CDT), for which the atomic abundance ratio ${ }^{34} \mathrm{~S} /{ }^{32} \mathrm{~S}$ is 0.0450045 (Ault and Kulp, 1959).

Generally, sulphides in igneous rocks have an average $\delta^{34} \mathrm{~S}$ close to $0 \%$ and are isotopically similar to those in meteorites or in mantle derived rocks (Faure, 1986). Sea water and sedimentary sulphates, however, are enriched in the heavy isotope $\left({ }^{34} \mathrm{~S}\right)$ by approximatively 10 to $30 \%$, depending on the geologic age (Claypool et al., 1980). Contemporaneous sedimentary sulphides have a wide range of isotopic compositions which are generally enriched in light $\delta^{32} \mathrm{~S}$ isotopes (Krouse, 1980; Faure, 1986).

Until recently, sulphur isotopic studies have been used to investigate the variability in 
$\delta^{34} \mathrm{~S}$ values and their deviations from upper mantle sulphur and oceanic sulphur. It is now well realized that data on sulphur composition alone are usually insufficient to define the sulphur source of an ore because large isotopic fractionations are involved in almost all the chemical reactions involved in mineralization (Ohmoto, 1972). Consequently, the accurate estimation of a sulphur source generally requires many additional data (such as $\mathrm{pH}, \mathrm{fO}_{2}$, and $T$ ) because oxidation-reduction processes induce large isotopic fractionations between sulphides and coeval dissolved sulphates (Ohmoto, 1972; Arnold and Sheppard, 1981). Similar difficulties occur if bacterial sulphate reducers are involved in near surface marine environments because the isotopic composition of biogenic $\mathrm{SH}_{2}$ depends upon nutrient supply, reduction rate, sulphate concentration, and temperature (Harrison and Thode, 1957). Fortunately, such a difficulty is not encountered in the present study because only very small fractionation effects are involved both in the oxidation of sulphides into sulphates at low temperatures and in gypsum crystallization (Thode and Monsters, 1965; Krouse, 1980; Pearson and Rightmire, 1980).

\section{Materials and methods}

\subsection{Gypsum sampling}

In order to determine the origin of gypsum in Vertisols, its isotopic composition is compared with the $\delta^{34} \mathrm{~S}$ values of evaporitic marine gypsum $\left(\delta^{34} S\right.$ of seawater $\sim 20.9 \%$; Rees et al., 1978) and with continental gypsum derived from the oxidation of sulphides. Two samples of evaporitic marine gypsum were obtained from the coastal Mara Marsh (Fig. 3, No. 5), near the surface of a bare flat between the mangrove and the coast. One of these gypsum samples, from a reddish clay layer containing kaolinite and illite, had an acicular form. The other sample was from a black organic layer, immediately beneath the reddish clay layer, and had a trapezohedron form (Baltzer, 1970). A third sample of evaporitic marine gypsum had a powdery aspect, and is obtained from a stratified bed in a cave, close to the sea level near Nepoui (Fig. 3, No. 13). Samples of continental sulphate formed by surficial oxidation of chalcopyrite and pyrite were obtained from wastes from an old copper mine near Poya (Fig. 3, No. 12) and from Hunter Island (Fig. 1), where crystals are produced by low temperature volcanic activity (Maillet and Monzier, 1982).

A total of 26 gypsum crystals were sampled in New Caledonian Vertisols at various altitudes and distances from the shoreline (Fig. 3). Most of the samples were obtained from Vertisols on colluvium, derived from different types of parent rock (flysch, limestone, basalt) at varying depths. Other samples were collected in old alluvial terraces derived from the weathering of parent rocks, that included basalt, graywackes, shales, and terrigenous sandstones rich in organic matter and sulphides. These Vertisols from the alluvial terraces are more sodic and acidic than the Vertisols on the colluvium (Table 1).

\subsection{Analytical method}

Crystals of gypsum for analysis generally contain various impurities such as clays, carbonates, fluid inclusions, and iron hydroxides. For this reason, the gypsum crystals were 
crushed, and then dissolved in double distillated cold water. The solution was filtered and anhydrite was produced by means of evaporation at approximately $80^{\circ} \mathrm{C}$. The powdered anhydrite was mixed with silica and ignited at $1500^{\circ} \mathrm{C}$ in an evacuated furnace to produce $\mathrm{SO}_{2}$. The sulphur dioxide was continuously trapped at $-190^{\circ} \mathrm{C}$ by means of liquid nitrogen, both to prevent sulphur trioxide from being formed and to produce the following reaction:

$$
\mathrm{CaSO}_{4}+\mathrm{SiO}_{2} \rightarrow \mathrm{CaSiO}_{3}+\mathrm{SO}_{2}+\frac{1}{2} \mathrm{O}_{2}
$$

After heating the $\mathrm{SO}_{2}$, the gas was purified by traps at $-40^{\circ} \mathrm{C}$ and $-110^{\circ} \mathrm{C}$. The first treatment eliminated traces of $\mathrm{H}_{2} \mathrm{O}$ and $\mathrm{SO}_{3}$, and the second eliminated $\mathrm{CO}_{2}$. The reaction rate was measured by means of a mercury manometer. The isotopic analyses were performed by a double collector VG 602D mass spectrometer. Analytical reproducibility was usually better than $0.05 \%$. The laboratory standard (commercial $\mathrm{SO}_{2}$ ) was periodically calibrated against the five international standards produced by Monsters and Rees (1975). The measured values were then standardized in relation to the CDT (Cañon Diablo Troilite).

\section{Isotopic data}

All the isotopic measurements (Tables 2, 3, and 4) are from samples obtained from the locations depicted in Fig. 3. Table 2 shows five $\delta^{34} \mathrm{~S}$ values for gypsum crystals formed under purely continental and purely marine conditions. In the first case, $\delta^{34} \mathrm{~S}$ grades from $-5 \%$ (on the volcanic Hunter Island) to $+1 \%$ (wastes of Poya Copper Mine). This range

Table 2

General characteristics of gypsum from continental and marine origins in New Caledonia

\begin{tabular}{|c|c|c|c|c|c|c|c|}
\hline Sample & $\begin{array}{l}\text { Geographic } \\
\text { location }^{\text {a }}\end{array}$ & $\begin{array}{l}\text { Gypsum } \\
\text { morphology }\end{array}$ & $\begin{array}{l}\text { Crystal } \\
\text { size } \\
(\mathrm{cm})\end{array}$ & $\begin{array}{l}\text { Pedological } \\
\text { environment }\end{array}$ & $\begin{array}{l}\text { Geomorphological } \\
\text { environment }\end{array}$ & $\begin{array}{l}\text { Distance } \\
\text { from the } \\
\text { sea }(\mathrm{km})\end{array}$ & $\delta^{34} \mathrm{~S}$ \\
\hline POY 1 & $\begin{array}{l}\text { Poya, } \\
\text { Honfleur } \\
\text { mine }^{12}\end{array}$ & $\begin{array}{l}\text { fibrous } \\
\text { gypsum }\end{array}$ & $1-5$ & $\begin{array}{l}\text { Chalcopyrite, } \\
\text { pyrite }\end{array}$ & $\begin{array}{l}\text { coppermine } \\
\text { wastes }\end{array}$ & 8 & $\begin{array}{l}0.99 \pm 0.05 \\
0.97 \pm 0.05\end{array}$ \\
\hline HUN 1 & $\begin{array}{l}\text { Hunter island, } \\
\text { volcanic arc }\end{array}$ & $\begin{array}{l}\text { automorphous } \\
\text { prisms, } \\
\text { transluscent }\end{array}$ & $1-5$ & sulfur, andesite & $\begin{array}{l}\text { cave beneath lava } \\
\text { flow, active } \\
\text { volcano }\end{array}$ & $<0.5$ & $\begin{array}{l}-3.81 \pm 0.05 \\
-4.34 \pm 0.05\end{array}$ \\
\hline MRA 22 & $\begin{array}{l}\text { Moindou, } \\
\text { Mara Marsh }\end{array}$ & $\begin{array}{l}\text { acicular gypsum, } \\
\text { sticks }\end{array}$ & $1-5$ & $\begin{array}{l}\text { kaolinite-illite } \\
\text { clay }\end{array}$ & $\begin{array}{l}\text { mársh, mangrove, } \\
\text { bare flats }\end{array}$ & 0 & $19.23 \pm 0.05$ \\
\hline MRA 12 & $\begin{array}{l}\text { Moindou, } \\
\text { Mara Marsh }^{5}\end{array}$ & $\begin{array}{l}\text { trapezohedron, } \\
\text { lenticular }\end{array}$ & $\begin{array}{l}0.5- \\
1.5\end{array}$ & $\begin{array}{l}\text { Black organic } \\
\text { matter }\end{array}$ & $\begin{array}{l}\text { marsh, mangrove, } \\
\text { bare flats }\end{array}$ & 0 & $16.73 \pm 0.05$ \\
\hline NEP 1 & $\begin{array}{l}\text { Poya- } \\
\text { Nepoui }^{13}\end{array}$ & $\begin{array}{l}\text { powdery gypsum } \\
\text { continuous level }\end{array}$ & $<0.1$ & smectites & $\begin{array}{l}\text { gypsum layer in a } \\
\text { cave, karst }\end{array}$ & $<1$ & $\begin{array}{l}19.48 \pm 0.05 \\
19.20 \pm 0.05\end{array}$ \\
\hline
\end{tabular}

${ }^{\text {anumbers refer to Fig. } 3 .}$ 
Table 3

General characteristics of gypsum located on old alluvial terraces in New Caledonia

\begin{tabular}{|c|c|c|c|c|c|c|c|c|}
\hline Sample & $\begin{array}{l}\text { Geographic } \\
\text { location }^{\mathrm{a}}\end{array}$ & $\begin{array}{l}\text { Gypsum } \\
\text { morphology }\end{array}$ & $\begin{array}{l}\text { Crystal } \\
\text { size } \\
(\mathrm{cm})\end{array}$ & $\begin{array}{l}\text { Pedological } \\
\text { environment }\end{array}$ & $\begin{array}{l}\text { Geomorphological } \\
\text { environment }\end{array}$ & $\begin{array}{l}\text { Altitude } \\
(\mathrm{m})\end{array}$ & $\begin{array}{l}\text { Distance } \\
\text { from the } \\
\text { sea } \\
(\mathrm{km})\end{array}$ & $\delta^{34} \mathrm{~S}$ \\
\hline TOM 000 & $\begin{array}{l}\text { Oua-Tom River } \\
\text { Boulouparis }^{4}\end{array}$ & $\begin{array}{l}\text { agglomerate } \\
\text { crystals }\end{array}$ & $1-3$ & smectites & $\begin{array}{l}\text { high alluvial } \\
\text { terrace }\end{array}$ & 20 & 2.5 & $\begin{array}{l}19.65 \pm 0.05 \\
12.40 \pm 0.05 \\
13.74 \pm 0.05 \\
13.27 \pm 0.05\end{array}$ \\
\hline TOM 1 & $\begin{array}{l}\text { Oua-Tom River, } \\
\text { Boulouparis }^{4}\end{array}$ & lenticular & $0.5-3$ & smectites & $\begin{array}{l}\text { high alluvial } \\
\text { terrace }\end{array}$ & 20 & 2.5 & $\begin{array}{l}13.55 \pm 0.06 \\
14.37 \pm 0.04\end{array}$ \\
\hline FOA 1 & $\begin{array}{l}\text { Pocquereux } \\
\text { River, La Foa }\end{array}$ & $\begin{array}{l}\text { agglomerate } \\
\text { crystals }\end{array}$ & $1-3$ & smectites & $\begin{array}{l}\text { high alluvial } \\
\text { terrace }\end{array}$ & 20 & 10 & $12.10 \pm 0.06$ \\
\hline PBT 1 & $\begin{array}{l}\text { Pouembout } \\
\text { River, } \\
\text { Pouembout }^{14}\end{array}$ & $\begin{array}{l}\text { agglomerate } \\
\text { crystals }\end{array}$ & $1-3$ & smectites & $\begin{array}{l}\text { high alluvial } \\
\text { terrace }\end{array}$ & 20 & 7 & $\begin{array}{l}12.52 \pm 0.04 \\
12.11 \pm 0.05\end{array}$ \\
\hline
\end{tabular}

${ }^{a}$ Numbers refer to Fig. 3. 


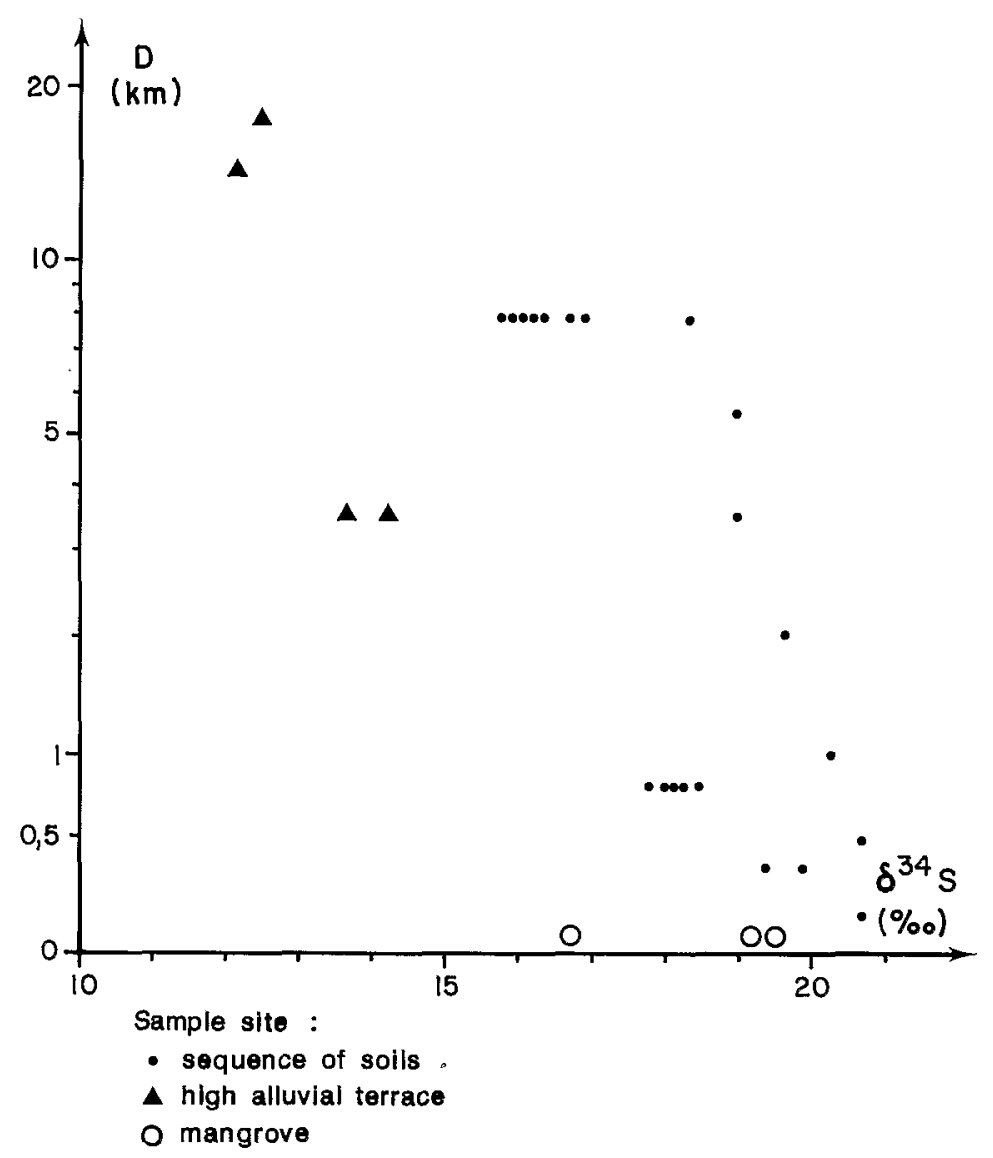

Fig. 4. Isotopic composition of samples related to the distance from the sea.

of $\delta^{34} \mathrm{~S}$ variation is considered to represent the continental end member of the gypsum formation processes.

The New Caledonian gypsum crystals formed in coastal marine marshes are comparatively strongly enriched in heavy isotopes. Three marine samples have $\delta^{34} \mathrm{~S}$ values close to $20 \%$ (Table 2). It is important to emphasize that one of the samples is significantly enriched in light isotopes with a $\delta^{34} \mathrm{~S}$ value close to $17 \%$. The range of $\delta^{34} \mathrm{~S}$ values observed in Mara Marsh does not indicate a natural variation of the $\delta^{34} S$ of sea water. Gypsum crystals whose $\delta^{34} S$ values are close to $17 \%$ are coated by ferric hydroxides and embedded in organic matter. This situation indicates that the marine gypsum has been contaminated locally by a component enriched in light isotopes. Because gypsum is associated with organic matter and iron hydroxides, it is conceivable that bacteriogenic iron sulphides, low in ${ }^{34} \mathrm{~S}$ (Rees, 1973) were oxidized into sulphates during a temporary drying of the Mara Marsh (Baltzer, 1970). Thus, mixing of light and heavy sulphate compounds may have produced this intermediate $\delta^{34} \mathrm{~S}$ value. 
General characteristics of gypsum obtained from soil sequences in New Caledonia.

\begin{tabular}{|c|c|c|c|c|c|c|c|c|}
\hline Sample & $\begin{array}{l}\text { Geographic } \\
\text { location }\end{array}$ & $\begin{array}{l}\text { Gypsum } \\
\text { morphology }\end{array}$ & $\begin{array}{l}\text { Crystal } \\
\text { size }(\mathrm{cm})\end{array}$ & $\begin{array}{l}\text { Pedological } \\
\text { environment }\end{array}$ & $\begin{array}{l}\text { Geomorphological } \\
\text { environment }\end{array}$ & $\begin{array}{l}\text { Altitude } \\
(\mathrm{m})\end{array}$ & $\begin{array}{l}\text { Distance } \\
\text { from the } \\
\text { sea } \\
(\mathrm{km})\end{array}$ & $\delta^{34} \mathrm{~S}$ \\
\hline MER 537 & La Tamoa Païta ${ }^{2}$ & $\begin{array}{l}\text { agglomerate } \\
\text { black crystals }\end{array}$ & $0.2-1$ & $\begin{array}{l}\text { smectite } \mathrm{MnO}_{2} \\
\text { level }\end{array}$ & sequence on flysch & 20 & $6-8$ & $18.39 \pm 0.05$ \\
\hline MER 639 & La Tamoa Païta ${ }^{2}$ & lenticular & $0.5-3$ & smectite & sequence on flysch & 20 & $6-8$ & $16.41 \pm 0.05$ \\
\hline MER 6310 & La Tamoa Païta ${ }^{2}$ & $\begin{array}{l}\text { agglomerate } \\
\text { black crystals }\end{array}$ & $1-10$ & $\begin{array}{l}\text { smectite, } \mathrm{MnO}_{2} \\
\text { level }\end{array}$ & sequence on fiysch & 20 & $6-8$ & $16.85 \pm 0.05$ \\
\hline MER 6311 & La Tamoa Païta ${ }^{2}$ & $\begin{array}{l}\text { agglomerate } \\
\text { crystals }\end{array}$ & $1-10$ & $\begin{array}{l}\text { smectite beneath } \\
\mathrm{MnO}_{2} \text { level }\end{array}$ & sequence on fiysch & 20 & $6-8$ & $16.90 \pm 0.05$ \\
\hline MER 546 & La Tamoa Païta ${ }^{2}$ & lenticular & $0.5-3$ & smectite & sequence on flysch & 20 & $6-8$ & $16.70 \pm 0.05$ \\
\hline MER 647 & La Tamoa Païta ${ }^{2}$ & lenticular & $0.5-3$ & smectite & sequence on flysch & 20 & $6-8$ & $15.82 \pm 0.05$ \\
\hline MER 6410 & La Tamoa Païta ${ }^{2}$ & $\begin{array}{l}\text { agglomerate } \\
\text { crystals }\end{array}$ & $1-10$ & $\begin{array}{l}\text { smectite beneath } \\
\mathrm{MnO}_{2} \text { level }\end{array}$ & sequence on flysch & 20 & $6-8$ & $15.91 \pm 0.05$ \\
\hline LEP 135 & Lepredour Island $^{3}$ & $\begin{array}{l}\text { lenticular } \\
\text { red-beige }\end{array}$ & $0.3-2$ & yellow smectite & $\begin{array}{l}\text { doline; sequence } \\
\text { on limestone }\end{array}$ & 170 & $0.5-0.7$ & $18.22 \pm 0.05$ \\
\hline LEP 136 & Lepredour Island $^{3}$ & $\begin{array}{l}\text { lenticular } \\
\text { red-beige }\end{array}$ & $\begin{array}{l}0.2-3 \\
\text { smectite }\end{array}$ & $\begin{array}{l}\text { yellow and red } \\
\text { on limestone }\end{array}$ & doline; sequence & 170 & $0.5-0.7$ & $17.84 \pm 0.05$ \\
\hline
\end{tabular}




\begin{tabular}{|c|c|c|c|c|c|c|c|c|}
\hline LEP 235 & Lepredour Island $^{3}$ & red lenticular & $0.1-1$ & red smectite & $\begin{array}{l}\text { doline; sequence } \\
\text { on limestone }\end{array}$ & 170 & $0.5-0.7$ & $18.15 \pm 0.05$ \\
\hline LEP 255 & Lepredour Island $^{3}$ & $\begin{array}{l}\text { lenticular } \\
\text { red-beige }\end{array}$ & $0.2-0.3$ & $\begin{array}{l}\text { yellow } \\
\text { smectite }\end{array}$ & $\begin{array}{l}\text { doline; sequence } \\
\text { on limestone }\end{array}$ & 170 & $0.5-0.7$ & $18.17 \pm 0.05$ \\
\hline LEP 257 & Lepredour Island ${ }^{3}$ & $\begin{array}{l}\text { agglomerate } \\
\text { red crystals }\end{array}$ & $1-20$ & red smectite & $\begin{array}{l}\text { doline; sequence } \\
\text { on limestone }\end{array}$ & 170 & $0.5-0.7$ & $18.52 \pm 0.05$ \\
\hline LEP 377 & Lepredour Island ${ }^{3}$ & lenticular & $0.1-1$ & weathered flysch & sequence on flysch & 10 & 0.2 & $19.43 \pm 0.05$ \\
\hline LEP 386 & Lepredour Island $^{3}$ & lenticular & $0.1-1$ & weathered flysch & sequence on flysch & 10 & 0.2 & $\begin{array}{l}19.30 \pm 0.05 \\
19.89 \pm 0.05\end{array}$ \\
\hline TIA 1 & Tiare Païta $^{1}$ & lenticular & $0.2-3$ & smectite & sequence on flysch & 10 & 0.5 & $20.60 \pm 0.04$ \\
\hline GOU 1 & $\begin{array}{l}\text { Gouaro } \\
\text { Bourail }^{7}\end{array}$ & lenticular & $0.2-3$ & smectite & sequence on flysch & 10 & $1-1.5$ & $\begin{array}{l}19.79 \pm 0.06 \\
20.12 \pm 0.03\end{array}$ \\
\hline CAP 1 & $\begin{array}{l}\text { downstream Cap } \\
\text { River }^{8}\end{array}$ & lenticular & $0.2-10$ & smectite & sequence on basalt & 10 & $0.1-1$ & $20.79 \pm 0.05$ \\
\hline CAP 2 & Cap road Bourail ${ }^{9}$ & lenticular & $0.2-3$ & smectite & sequence on basalt & 80 & $5-15$ & $19.06 \pm 0.03$ \\
\hline POY 2 & Beaupre Poya ${ }^{11}$ & Ienticular & $0.2-20$ & smectite & sequence on basalt & 10 & $0.5-2$ & $20.72 \pm 0.04$ \\
\hline POY 3 & Beaupre Poya ${ }^{10}$ & lenticular & $0.2-3$ & smectite & sequence on basalt & 70 & $4-6$ & $19.04 \pm 0.05$ \\
\hline $\mathrm{ACO} 1$ & Taom Ouaco & lenticular & $0.2-20$ & smectite & sequence on basalt & 15 & $3-3$ & $19.48 \pm 0.06$ \\
\hline
\end{tabular}




\section{Gypsum in Vertisols}

Tables 3 and 4 show the following information:

(1) In the colluvial Vertisols, most of the $\delta^{34} S$ values of gypsum are close to the marine sulphate composition; the other values are intermediate between marine and continental sulphate compositions.

(2) The values of $\delta^{34} \mathrm{~S}$ from gypsum in colluvial Vertisols are not related to the nature of the parent rock, to the depth of sampling, or to the position of the gypsum in the catena.

(3) In Vertisols, the lowest values of $\delta^{34} S$ are from gypsum located in old alluvial terraces.

(4) The $\delta^{34} \mathrm{~S}$ values of gypsum decreases with increasing altitude and with increasing distance from the shoreline measured parallel to the direction of the trade winds (Fig. 4).

\section{Discussion}

The crystallization of gypsum from a water table in contact with sea water (evaporitic marine origin) or with sufide-rich rocks (continental origin) has been described by Stoops and Ilaiwi (1981), Warren (1982), and Akpokodje (1984). In addition to the "gypsiferous black clays" observed on topographically flat surfaces by Routhier (1953) and Avias (1963), many of the New Caledonian gypsiferous colluvium Vertisols are located on slopes with grades greater than $10 \%$. No signs of a fossil water table are visible in colluvium Vertisols.

In addition to water table activity, organic matter can also concentrate sulphur, particulary in swamps (Probert 1983; Williams and Raupach, 1983) and in old mangroves (Van Breemen, 1982; Doner and Lynn, 1989). However, in the New Caledonian Vertisols, no signs of an old organic layer or of mangrove tree roots are visible. The amounts of topsoil organic matter in New Caledonian Vertisols are low (2 to 5\%). Unlike the marine gypsum from the Mara Marsh, gypsum from Vertisols on colluvium is associated with smectite instead of kaolinite and illite, the gypsum crystals are found at depths greater than $0.80 \mathrm{~m}$ (instead of $40 \mathrm{~cm}$ ), and the form of the crystals is lenticular instead of acicular and trapezohedral.

The isotopic data suggest that the gypsum comes from the following two sources:

- a dominant marine source, probably introduced as sulphate by atmospheric precipitation, which affects essentially Vertisols on colluvium. According to Krouse (1980) sea spray sulphate should have the same $\delta^{34} S$ value as sea water $(\sim 20.9 \%$ ), assuming that only mechanical transport takes place;

- a continental source low in ${ }^{34} \mathrm{~S}$ (Table 2), which is derived from the oxydation of sulphur in geological materials; this source affects mainly Vertisols on alluvium. This sulphur occurs in the form of pyrite, mostly in Anisian or Senonian shales (Paris, 1981) which lie parallel to the long axis of New Caledonia. Because most of the streams flow perpendicular to this long axis, weathered shale residues are found downstream in alluvial terraces. 


\subsection{The rain inputs}

At the shoreline, the sulphur budget for gypsum crystals is dominated by marine sulphate introduced by rain and by dry depositions. Isotopic compositions are close to the marine compositions. For New Caledonia, the $\delta^{34} \mathrm{~S}$ values of gypsum decrease inland. A similar situation has been identified by Faure and Jones (1989) on Ross Island (Antarctica). They distinguished salts with a high $\delta^{34} \mathrm{~S}$ value $(+19.6 \%$ ) near the coast, derived from aerosols or rainfall, and salts with a very low $\delta^{34} \mathrm{~S}$ value $(+0.8 \%$ ) derived from the weathering of recent volcanic rocks. As in New Caledonia, the abundance of marine salts at Ross Island decreases with increasing elevation above sea level and with increasing distances from the coast.

In New Càledonia, the oceanic influence on $\delta^{34} \mathrm{~S}$ values decreases rapidly with increasing distances from the coast measured parallel to the tradewind direction. As this oceanic influence decreases, the relative importance of continental sulphate increases consequently. This relation is found in many South Pacific locations (Hingston and Gailitis, 1976; Blackburn and McLeod, 1983; Ledgard and Upsdell, 1991). All the New Caledonian gypsum soils are found within $20 \mathrm{~km}$ of the coast. The gypsum soils are exposed to the trade winds 200 days a year, at wind velocities ranging from 4 to $8 \mathrm{~m} \mathrm{~s}^{-1}$ (Bauduin and Brunel, 1981). The gypsum soils are also frequently exposed to tropical cyclones. These southeasterly trade winds, which are important in the north and northeast of Australia and in New Caledonia today, would have maintained their direction during the Quaternary Period (Coudray, 1975; Beckmann, 1983). A similar conclusion is suggested by Isbell et al. (1983) in their study of the origin of soluble salts in Australian soils.

Table 5 shows chemical data collected in Noumea during cyclone Lili (10-11 April 1989) and the mean values compiled by Berner and Berner (1985). Rainwater collected during this cyclone at distances less than $1 \mathrm{~km}$ from the coast is clearly enriched in soluble

\section{Table 5}

Chemical composition of rainwater

\begin{tabular}{|c|c|c|c|c|c|c|c|}
\hline \multirow[t]{2}{*}{ Ion } & \multicolumn{2}{|c|}{$\begin{array}{l}\text { Nouméa } \\
\text { New Caledonia } \\
\text { Cyclone Lilia }\end{array}$} & \multirow{2}{*}{$\begin{array}{l}\text { World } \\
\text { Coastal } \\
\text { Average } \\
{[3]}\end{array}$} & \multirow{2}{*}{$\begin{array}{l}\text { North } \\
\text { Atlantic } \\
\text { Ocean } \\
{[3]}\end{array}$} & \multirow{2}{*}{$\begin{array}{l}\text { Hawaï } \\
{[3]}\end{array}$} & \multirow{2}{*}{$\begin{array}{l}\text { Amsterdam } \\
\text { Island } \\
\text { Indian Oc. } \\
\text { [3] }\end{array}$} & \multirow{2}{*}{$\begin{array}{l}\text { W. Ireland } \\
\text { Coast } \\
{[3]}\end{array}$} \\
\hline & {$[1]$} & [2] & & & & & \\
\hline \multicolumn{8}{|c|}{ Values in $\mathrm{mg} / \mathrm{l}$} \\
\hline $\mathrm{Cl}-$ & 15.98 & 93.37 & 6.00 & 5.10 & 9.63 & 7.38 & 36.42 \\
\hline $\mathrm{SO}_{4}^{2-}$ & 3.84 & 13.44 & 1.45 & 1.20 & 1.92 & 1.47 & 6.29 \\
\hline $\mathrm{Ca}^{2+}$ & 0.80 & 4.81 & 0.29 & 0.20 & 0.47 & 0.15 & 1.52 \\
\hline $\mathrm{Mg}^{2+}$ & 1.34 & 6.56 & 0.45 & 0.20 & 0.92 & 0.46 & 2.59 \\
\hline $\mathrm{Na}^{+}$ & 9.20 & 52.44 & 3.45 & 2.80 & 5.46 & 4.07 & 21.00 \\
\hline \multicolumn{8}{|c|}{ Values in meq $/$} \\
\hline $\mathrm{SO}_{4}^{2-}$ & 0.08 & 0.28 & 0.03 & 0.03 & 0.04 & 0.03 & 0.13 \\
\hline $\mathrm{Ca}^{2+}$ & 0.04 & 0.24 & 0.01 & 0.01 & 0.02 & 0.01 & 0.07 \\
\hline
\end{tabular}

'10-11 April 1989.

Sources: [1] and [2]: Podwojewski (unpubl. data); [3] Berner and Berner (1985). 
salts as compared to the global mean values compiled by Berner and Berner (1985). For a rainfall of 400 to $800 \mathrm{~mm}$ per year, and with sulphate concentrations in the rain varying from 1 to $2 \mathrm{mg}^{-1}$, the amount of sulphate input by rainfall ranges from 0.4 to $1.6 \mathrm{~kg} \mathrm{~m}^{-2}$ $1000 \mathrm{yr}^{-1}$ ( 4 to $16 \mathrm{~kg} \mathrm{ha}^{-1} \mathrm{yr}^{-1}$ ). These values are similar to the mean value of $1.5 \mathrm{~kg}$ $\mathrm{ha}^{-1} \mathrm{yr}^{-1}$ of sulphate input by rainfall registered in southwest Australia (Hingston and Gailitis, 1976). The importance of the rainfall input of sulphates in the southwest Pacific is confirmed by the following recent measures: $1.9 \mathrm{~kg} \mathrm{~m}^{-2} 1000 \mathrm{yr}^{-1}$ for the Tonga Islands (Manu et al. 1990) and 0.15 to $4.5 \mathrm{~kg} \mathrm{~m}^{-2} 1000 \mathrm{yr}^{-1}$ for New Zealand (Ledgard and Upsdell, 1991).

New Caledonian Vertisols developed on old alluvium and colluvium probably during the Late Pleistocene glaciation. During the maximum of this glaciation (18,000 B.P.), the climate in North Australia was much drier than today (Kershaw, 1974; Bowler et al., 1976; Webster and Streten, 1978; Coventry et al., 1980). The winds, favourable to the transport of the salts, and to the concentration of salts in the soils by evaporation, were much stronger than today (Lorius et al., 1979; Petit et al., 1981).

\subsection{How Vertisols trap gysum}

Based on the fact that gypsum appears only in deep Vertisols, the following hypothesis can be made. Vertisols are recognized by their ability to shrink when dried and to swell when moistened. Vertical cracks develop during the dry season. During the rainy season, water and salts enter the soil profile through these vertical cracks to depths of about 60-70 $\mathrm{cm}$. The cracks, filled with water (and salt) then begin to close (Talsma and Van der Lelij, 1976; Bouma and Loveday, 1988). As described by Bouma et al. (1977) and Bouma and Wösten (1979) the base of the cracks (vertical planar rough voids) passes into smooth planar oblique voids. The swelling keeps these smooth oblique voids water tight so that at $1.00 \mathrm{~m}$ depth the soil moisture is constant throughout the year (Adams and Hanks, 1964; Selim and Kirkam, 1970). During the dry season, the soil shrinks, the vertical cracks reopen, water evaporates, and the salts stay deeply buried within the soil. This evaporation is a function of the wind velocity, and the depth and the width of the vertical cracks (Adams et al., 1969; Jouany, 1981). Because they do not have cracks and/or rain runoff over their surface, could be the reason why deep clayey soils (Planosols, Solonetz) contain very low concentrations of salts and no gypsum.

\section{Conclusions}

Measurements of the $\delta^{34} \mathrm{~S}$ of gypsum crystals occurring in Vertisols on the western coast of New Caledonia suggest that the gypsum in the Vertisols comes from the following two sources: an oceanic source where the major part of the sulphur is introduced as sulphate by atmospheric precipitation driven by the trade winds and by frequent cyclones, and a continental source where sulphides disseminated in various subsurface deposits are oxidized. Vertical cracks formed during dry seasons may trap and concentrate gypsum in deep horizons. This phenomenon was probably favored during the last glacial period, which was more dry and windy than today. 


\section{References}

Adams, J.E. and Hanks, R.J., 1964. Evaporation from soil shrinkage cracks. Soil Sci. Soc. Am. Proc., 28: 281284.

Adams, J.E., Ritchie, J.T.R., Burnett, E. and Fryrear, D.W., 1969. Evaporation from a simulated soil shrinkage crack. Soil Sci. Soc. Am. Proc., 33: 609-613.

Akpokodje, E.G., 1984. The influence of rock weathering on the genesis of gypsum and carbonate in some australian arid zone soils. Aust. J. Soil Res., 22: 243-251.

Arnold, M. and Sheppard, S.M.F., 1981. East Pacific rise at $21^{\circ}$ N. Isotopic composition and origin of the hydrothermal sulfur. Earth Planet Sci. Lett., 56: 148-156.

Ault, W.U. and Kulp, J.L., 1959. Isotope geochemistry of sulphur. Geochim. Cosmochim. Acta, 16: 201-235.

Avias, J., 1963. A propos des vases bariolées gypsifères actuelles de Nouvelle-Calédonie et sur la genèse des marnes bariolées salifères du Trias. Mém. Bur. Rech. Géol. Min., 15: 615-622.

Baltzer, F., 1970. Etude sêdimentologique du marais de Mara (Côte ouest de la Nouvelle-Calédonie) et des formations quaternaires voisines. Fondation Singer-Polignac, 4: 1-135.

Bauduin, D. and Brunel, J.P., 1981. Hydrologie. Planche 12, In: Atlas de la Nouvelle Calédonie. ORSTOM, Paris, $53 \mathrm{pp}$.

Beckmann, G.G., 1983. Development of old landscapes and soils. In: Soils: An Australian Viewpoint. Div. of Soils, CSIRO, Melbourne/Academic Press, London, pp. 51-72.

Berner, E.K. and Berner, R.A., 1985. The Global Water Cycle. Prentice-Hall, Englewood Cliffs, NJ, 398 pp.

Blackburn, G. and McLeod, S., 1983. Salinity of atmospheric precipitation in the Murray-Darling Drainage Division. Aust. J. Soil Res., 21: 411-434.

Bloom, A.L., Broecker, W.S., Chappel, J.M.A., Matthews, R.K. and Mesolella, K.J., 1974. Quaternary sea level fluctuations on a tectonic coast: $\mathrm{New}^{230} \mathrm{Th} /{ }^{234} \mathrm{U}$ dates from the Huon peninsula, New Guinea. Quat. Res., 4: $185-205$.

Bouma, J. and Loveday, J., 1988. Characterizing soil water regimes in swelling clay soils. In: L.P. Wilding and R. Puentes (Editors), Vertisols: Their Distribution, Properties, Classification and Management. SMSS, Texas A\&M, College Station, pp. 83-96.

Bouma, J. and Wösten, J.H.M., 1979. Flow patterns during extended saturated flow in two undisturbed clay soils. with different macrostructures. Soil Sci. Soc. Am. J., 43: 16-22.

Bouma, J., Jongerius, A., Boersma, O., Jager, A. and Schoonderbeek, D., 1977. The function of different types of macropores during saturated flow through four swelling soil horizons. Soil Sci. Soc. Am. J., 41: 945-950.

Bowler, J.M., Hope, G.S., Jennings, J.N., Singh, G. and Walker, D., 1976. Late Quaternary climates of Australia and New Guinea. Quat. Res., 6: 359-374.

Cabioch, G., 1988. Recifs frangeants de Nouvelle Calédonie. Thèse Université de Provence, Aix en Provence, $291 \mathrm{pp}$.

Claypool, G.E., Holser, W.T., Kaplan, I.R., Sakaï, H. and Zak, I., 1980. The age curves of sulfur and oxygen isotopes in marine sulfate and their mutual interpretation. Chem. Geol., 28: 199-260.

Coudray, J., 1975. Recherches sur le Néogène et le Quaternaire de la Nouvelle Calédonie: contribution de l'étude sédimentologique à la connaissance de l'histoire géologique post-Eocène. Thèse Doct. Etat Montpellier, 321 pp.

Coudray, J., 1977. The main events of sedimentary and structural history of New Caledonia from the Oligocene to the present day. Int. Symp. Geodyn. South-West Pacific, Nouméa, Technip. Ed., pp. 217-228.

Coventry, R.J., Hopley, D., Campbell, J.B., Douglas, I., Harvey, N., Kershaw, A.P., Oliver, J., Phipps, C.V.G. and Pye, K, 1980. The quaternary of northeastern Australia. In: R.A. Henderson and P.J. Stephenson (Editors), The Geology and Geophysics of Northeastern Australia. Geol. Soc. of Australia, Queensland Division, Brisbane, pp. 375-417.

Doner, H.E. and Lynn, W.C., 1989. Carbonate, halide, sulfate and sulfide minerals. In: J.B. Dixon and S.B. Weed (Editors), Minerals in Soil Environment, 1. 2nd ed. Soil Sci. Soc. of America, pp. 279-330.

Faure, G., 1986. Principles of Isotope Geology. 2nd ed. Wiley, New York, 689 pp.

Faure, G. and Jones, L.M., 1989. Distribution of marine salts along the west coast of Ross Island, Antarctica, 
based on isotopic compositions of strontium and sulfur. In: A. Bartho-Kyriakidis (Editor), Weathering, Its Products and Deposits. I. Processes. Theophrastus, Athens, pp. 369-381.

Gonord, H., 1977. Recherches sur la géologie de la Nouvelle-Calédonie, sa place dans l'ensemble structural du Pacifique sud-ouest. Thèse Doct., Etat Montpellier, $341 \mathrm{pp}$.

Harrison, A.G. and Thode, H.G., 1957. The kinetic isotope effect in the chemical reduction of sulfate. Trans. Farad. Soc., 53: $1-4$.

Hingston, F.J. and Gailitis, V., 1976. The geographic variation of salt precipitated over western Australia. Aust. J. Soil Res., 14: 319-335.

Isbell, R.F., Reeve, R. and Hutton, J.T., 1983. Salt and sodicity. In: Soils: An Australian Viewpoint. Div. of Soils, CSIRO, Melbourne/Academic Press, London, pp. 107-117.

Jouany, C., 1981. Transferts de l'eau par évaporation dans les milieux argileux. Doctorat 3ème cycle, Univ. P. Sabatier, Toulouse, $102 \mathrm{pp}$.

Kershaw, A.P., 1974. A long continuous pollen sequence from northeastern Australia. Nature, 251: 222-223.

Krouse, H.R., 1980. Sulphur isotopes in our environment. In: P. Fritz and J. Ch. Fontes (Editors), Handbook of Environmental Isotope Geochemistry, 1. Elsevier, Amsterdam, pp. 435-471.

Ledgard, S.F. and Upsdell, M.P., 1991. Sulphur inputs from rainfall throughout New Zealand. N. Z. J. Agric. Res., 34: 105-111.

Lorius, C., Merlivat, L., Jouzel, J, and Pourchet, M., 1979. A 30,000 yr climatic record from Antarctic ice. Nature, 280: 644-648.

Maillet, P. and Monzier, M., 1982. Volcanisme et pétrologie des îles Matthew et Hunter: données préliminaires. In: Contribution à l'Étude Géodynamique du Sud-Ouest Pacifique. Trav. Doc. ORSTOM, 147: 187-215.

Manu, V.T., Powell, H.K.J., Banks, L., Sheat, A. and Widdowson, J.P., 1990. Accession of $\mathrm{SO}_{4}{ }^{2-}$ sulfur from Tongan rainfall. Aust. J. Soil Res., 28: 727-736.

Monsters, J. and Rees, C.E., 1975. Sulphur isotopes secondary standards. Interlaboratory comparisons and discussions, McMaster Univ., Hamilton.

Ohmoto, H., 1972. Systematics of sulfur and carbon isotopes in hydrothermal ore deposits. Econ. Geol., 67: 551579.

Paris, J.P., 1981. Géologie de la Nouvelle Calédonie. Un essai de synthèse. Mémoires du BRGM, 113. BRGM, Orléans, 278 pp. +2 cartes au 1:200,000.

Pearson, F.J., Jr. and Rightmire, C.T., 1980. Sulphur and oxygene isotopes in aqueous sulphur compounds. In: P. Fritz and J.Ch. Fontes (Editors), Handbook of Environmental Isotope Geochemistry, 1. Elsevier, Amsterdam, pp. 227-258.

Petit, J.R., Briat, M. and Royer, A., 1981. Ice age aerosol content from East Antarctic ice core samples and past wind strength. Nature, 291: 391-394.

Podwojewski, P., 1988. Les vertisols de Nouvelle Calédonie, Cah. ORSTOM, Sér. Pédol., XXIV(4): 279-301.

Podwojewski, P. and Beaudou, A., 1991. Vertisols of New Caledonia; morphological, chemical and physical properties; and classification. In: J.M. Kimble (Editor), Proc. 6th Int. Soil Correlation Symp. (VI ISCOM): Characterization, Classification, and Utilization of Cold Aridisols and Vertisols. Soil Conservation Service, Soil Management Support Services, USDA, pp. 151-158.

Probert, M.E., 1983. Organic phosphorus and sulfur. In: Soils: An Australian Viewpoint. Div. of Soils, CSIRO, Melbourne/Academic Press, London, pp. 583-587.

Rees, C.E., 1973. A steady-state model for sulphur isotope fractionation in bacterial reduction processes. Geochim. Cosmochim. Acta, 37: 1141-1162.

Rees, C.E., Jenkins, W.J. and Monsters, J., 1978. The sulphur isotopic composition of ocean water sulphate. Geochim. Cosmochim. Acta, 42: 377-381.

Routhier, P., 1953. Etude géologique du versant occidental de la Nouvelle-Calédonie entre le col de Boghen et la pointe d'Arama. Mém. Soc. Géol. Fr., N.S., 32: 67, 1-127.

Selim, H.M. and Kirkham, D., 1970. Soil temperatures and water content changes during drying as infuenced by cracks: a laboratory experiment. Soil Sci. Soc. Am. Proc., 34: 565-569.

Stoops, G. and Ilaiwi, M., 1981. Gypsum in arid soils morphology and genesis. In: F.H. Beinroth and A. Osman (Editors), Proc. 3rd Soil Classification Workshop. ACSAD, Damas, pp. 175-198.

Talsma, T. and Van Der Lelij, A., 1976. Infiltration and water movement in an in situ swelling soil during prolonged ponding. Aust. J. Soil Res., 14: 337-349.

Thode, H.G. and Monsters, J., 1965. Sulfur isotope geochemistry of petroleum, evaporites and ancient seas. In: A. Young and J.E. Galley (Editors), Fluids Subsurface Environments Am. Assoc. Petrol. Geol. Symp. Mem., 4: $367-377$. 
Tucker, B.M., 1985. Laboratory procedures for soluble salts and exchangeable cations in soils. Tech. Pap. 47, Aust. Div. of Soils, CSIRO, Melbourne, pp. 1-36.

Van Breemen, N., 1982. Genesis, morphology, and classification of acid-sulfate soils in coastal plains. In: J.A. Kittrick (Editor), Acid Sulfate Weathering. Spec Publ. 10. SSSA, Madison WI, pp. 95-108.

Warren, J.K., 1982. The hydrological setting, occurence and significance of gypsum in late Quaternary salt lakes in south Australia. Sedimentology, 29: 609-637.

Webster, P.J. and Streten, N.A., 1978. Late Quaternary Ice Age of Tropical Australasia. Interpretations and reconstructions. Quat. Res., 10: 279-309.

Williams, C.H. and Raupach, M., 1983. Plant nutrients in Australian soils. In: Soils: An Australian Viewpoint. Div, of Soils, CSIRO, Melbourne/Academic Press, London, pp. 777-793. 


\section{Reprinted from}

\section{GEODERMA}

AN INTERNATIONAL JOURNAL OF SOIL SCIENCE

The origin of gypsum in Vertisols in New Caledonia determined by isotopic characteristics of sulphur

P. Podwojewski ${ }^{\mathrm{a}}$, M. Arnold ${ }^{\mathrm{b}}$

"Institut de Géologie, Université Louis Pasteur, 1 rue Blessig, 67084 Strasbourg Cedex, France

${ }^{b}$ Centre de Recherches Pétrographiques et Géochimiques, 15 rue N.D. des Pauvres, B.P. 20 ,

54501 Vandoeuvre-les-Nancy Cedex, France

Received November 21, 1991 ; accepted after revision November 12, 1993

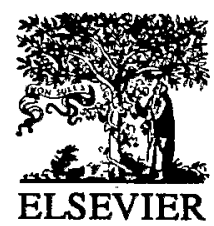

0. R. S.T. O. M. Fonds Documentaire.

$N: 41477$ ex 1

Cote: $B$ 